\title{
PENDIDIKAN KARAKTER DALAM PERSPEKTIF ISLAM
}

\author{
Oleh: Drs. Dahrun Sajadi, MA
}

\section{A. Abstrak}

Akhir-akhir ini semakin disadari betapa penting pendidikan karakter atau dalam Islam disebut dengan pendidikan akhlaq mulia (akhlaq karimah). Kecerdasan intelektual tanpa dibarengi karakter atau akhlaq yang mulia tidak akan ada gunanya. Karakter atau akhlaq adalah sesuatu yang sangat mendasar dan saling melengkapi. Manusia yang tidak berkarakter atau tidak berakhlaq mulia disebut sebagai manusia tak beradab dan tidak memiliki harga atau nilai. Karakter atau akhlaq mulia itu harus dibangun. Sedangkan membangun akhlaq mulia adalah melalui pendidikan, baik pendidikan di rumah (keluarga), di sekolah, maupun di masyarakat. Untuk membentuk karakter atau akhlaq mulia doperlukan pendidikan karakter dan pendidikan agama. Pendidikan sangat menentukan terhadap pembentukan watak, kepribadian, karakter dan budi pekerti manusia. Pendidikanlah yang paling bertanggung jawab atas fenomena kejahatan, tindak kriminal, perbuatan asusila, korupsi, penggunaan narkoba dan keburukankeburukan lainnya. Terjadinya berbagai penyelewengan dan kejahatan menandakan rendahnya karakter warga secara umum. Menyadari hal itu, perlulah diseriuskan program pendidikan karakter untuk meningkatkan kualitas individu dan masyarakat. Berkaitan dengan hal tersebut, dalam makalah ini akan dibahas mengenai pendidikan karakter dalam Islam.

Kata Kunci : Pendidikan, Karakter, Perspektif Islam

\section{B. Hakekat Pendidikan Karakter}

\section{Pengertian Karakter}

Secara etimologis, kata karakter (Inggris: character) berasal dari bahasa Yunani (Greek), yaitu charassein yang berarti "to engrave", 2 yang bisa diterjemahkan mengukir, melukis, memahatkan, atau Menggoreskan. ${ }^{3}$ Dalam Kamus Bahasa Indonesia, kata "karakter" diartikan tabiat, sifat-sifat kejiwaan, akhlaq atau budi pekerti yang membedakan seseorang dengan yang lain, dan watak. Karakter juga bisa berarti huruf, angka, ruang, simbol khusus yang dapat dimunculkan pada layar dengan papan ketik. ${ }^{4}$ Orang berkarakter berarti orang yang berkepribadian, berperilaku, bersifat, bertabiat, atau berwatak.

Dengan makna tersebut berarti karakter identik dengan kepribadian atau akhlaq. Kepribadian merupakan ciri atau karakteristik atau sifat khas dari diri seseorang yang bersumber dari bentukan-bentukan yang diterima dari lingkungan, misalnya keluarga pada masa kecil, dan juga bawaan sejak lahir. Seiring dengan pengertian ini, ada yang berpendapat bahwa baik buruknya karakter manusia sudah menjadi bawaan dari lahir. Jiwa bawaannya baik, maka manusia itu akan berkarakter baik, dan sebaliknya jika bawaannya jelek, maka

\footnotetext{
${ }^{1}$ Penulis: Dosen Fakultas Agama Islam Universitas Islam As-Syafi'iyah Jakarta.

${ }^{2}$ Kevin Ryan \& Karen E. Bohlin, Building Character in Schools: Practical, 1999.

${ }^{3}$ Echols, M. John dan Shadily, Hassan, Kamus Inggris Indonesia: An English-Indonesian Dictionary. Jakarta: PT Gramedia. Cet. XXI, 1995, h.214.

${ }^{4}$ Pusat Bahasa Departemen Pendidikan Nasional, Kamus Bahasa Indonesia, Jakarta: Pusat Bahasa. Cet.I, 2008, h.682.
} 
manusia itu akan berkarakter jelek. Jika pendapat ini benar, maka pendidikan karakter tidak ada gunanya, karena tidak akan mungkin merubah karakter orang yang sudah taken for granted. Sementara itu sekelompok orang yang lain berpendapat berbeda, yakni bahwa karakter bisa dibentuk dan diupayakan, sehingga pendidikan karakter menjadi sangat bermakna untuk membawa manusia dapat berkarakter yang baik.

Secara terminologis, makna karakter dikemukakan oleh Thomas Lickona. Menurutnya karakter adalah "A reliable inner disposition to respond to situations in a morally good way." Selanjutnya Lickona menambahkan, "Character so conceived has three interrelated parts: moral knowing, moral feeling, and moral behavior". Menurut Lickona, karakter mulia (good character) meliputi pengetahuan tentang kebaikan (moral khowing), lalu menimbulkan komitmen (niat) terhadap kebaikan (moral feeling), dan akhirnya benar-benar melakukan kebaikan (moral behaviour). Dengan kata lain, karakter mengacu kepada serangkaian pengetahuan (cognitives), sikap (attitides), dan motivasi (motivations), serta perilaku (behaviors) dan keterampilan (skills). ${ }^{5}$

Dapatlah dipahami bahwa karakter identik dengan akhlaq, sehingga karakter merupakan nilai-nilai perilaku manusia yang universal yang meliputi seluruh aktivitas manusia, baik dalam rangka berhubungan dengan Tuhannya, dengan dirinya, dengan sesama manusia, maupun dengan lingkungannya, yang terwujud dalam pikiran, sikap, perasaan, perkataan, dan perbuatan berdasarkan norma-norma agama, hukum, tata karma, budaya, dan adat istiadat. Dengan ungkapan lain, karakter cenderung diidentikkan dengan personalitas atau kepribadian. Orang yang memiliki karakter berarti memiliki kepribadian. Keduanya diartikan sebagai totalitas nilai yang dimiliki seseorang yang mengarahkan manusia dalam menjalani kehidupan. Totalitas nilai meliputi tabiat, akhlaq, budi pekerti dan sifat-sifat kejiawaan lainya. Karakter juga diartikan sebagai kumpulan tata nilai yang menuju pada suatu sistem yang melandasi pemikiran, sikap, dan prilaku yang ditampilkan. Perilaku tertentu seseorang, sikap atau pikirannya yang dilandasi oleh nilai tertentu akan menunjukkan karakter yang dimilikinya. Pengertian karakter di atas menunjukkan dua pengertian.

a. Karakter menunjukkan bagaimana seseorang bertingkah laku. Dimana prilaku tersebut merupakan manifestasi dari karakter. Orang yang berprilaku tidak jujur, rakus dan kejam, tentulah ia memanifestasikan perilaku/karakter buruk. Sebaliknya, apabila orang berperilaku jujur, suka menolong tentu orang tersebut memanifestasikan karakter mulia.

b. Istilah karakter berkaitan dengan dengan personality. Seseorang baru bisa disebut orang yang berkarakter (a person of character) apabila tingkah lakunya sesuai dengan kaidah moral.

Karakter merupakan sifat batin yang mempengaruhi segenap pikiran dan perbuatan. Apa yang seorang pikirkan dan perbuat sebenarnya merupakan dorongan dari karakter yang ada padanya. Dengan adanya karakter (watak, sifat, tabiat, ataupun perangai) seseorang dapat memperkirakan reaksi-reaksi dirinya terhadap fenomena yang muncul dalam diri ataupun hubungan dengan orang lain dalam berbagai keadaan serta bagaimana mengendalikannya. Karakter kadang diasosiasikan dengan dengan temperamen, seolah-olah

\footnotetext{
${ }^{5}$ Thomas Lickona, Educating for Character: How Our School Can Teach Respect and Responsibility. New York, Toronto, London, Sydney, Aucland: Bantam books, 1991, h. 51.
} 
merupakan definisi yang menekankan unsur psikososial, dikaitkan dengan pendidikan dan konteks lingkungan. ${ }^{6}$

\section{Pendidikan Karakter}

Dari konsep karakter ini muncul konsep pendidikan karakter (character education). Ahmad Amin menjadikan kehendak (niat) sebagai awal terjadinya akhlaq (karakter) pada diri seseorang, jika kehendak itu diwujudkan dalam bentuk pembiasaan sikap dan perilaku. ${ }^{7}$

Terminologi pendidikan karakter mulai dikenalkan sejak tahun 1900-an. Thomas Lickona dianggap sebagai pengusungnya, terutama ketika ia menulis buku yang berjudul The Return of Character Education dan kemudian disusul bukunya, Educating for Character: How Our School Can Teach Respect and Responsibility. Melalui buku-buku itu, ia menyadarkan dunia Barat akan pentingnya pendidikan karakter. Pendidikan karakter menurut Lickona mengandung tiga unsur pokok, yaitu mengetahui kebaikan (knowing the good), mencintai kebaikan (desiring the good), dan melakukan kebaikan (doing the good) (Lickona, 1991: 51). Frye mendefinisikan pendidikan karakter sebagai, "A national movement creating schools that foster ethical, responsible, and caring young people by modeling and teaching good character through an emphasis on universal values that we all share". ${ }^{8}$

Pendidikan karakter kemudian dijadikan gerakan nasional yang menjadikan sekolah sebagai agen untuk membangun karakter siswa melalui pembelajaran dan pemodelan. Melalui pendidikan karakter, sekolah harus berpretensi untuk membawa peserta didik memiliki nilai-nilai karakter mulia seperti hormat dan peduli pada orang lain, tanggung jawab, memiliki integritas, dan disiplin. Di sisi lain pendidikan karakter juga harus mampu menjauhkan peserta didik dari sikap dan perilaku yang tercela dan dilarang.

Lebih dari sekadar mengajarkan mana yang benar dan mana yang salah kepada anak, pendidikan karakter menanamkan kebiasaan (habituation) tentang yang baik sehingga peserta didik paham, mampu merasakan, dan mau melakukan yang baik. Dengan demikian, pendidikan karakter membawa misi yang sama dengan pendidikan akhlaq atau pendidikan moral. Selanjutnya Frye menegaskan bahwa pendidikan karakter merupakan usaha yang disengaja untuk membantu seseorang memahami, menjaga, dan berperilaku yang sesuai dengan nilai-nilai karakter mulia. ${ }^{9}$

Kini pendidikan karakter menjadi suatu sistem penanaman nilai-nilai karakter kepada warga terdidik yang meliputi komponen pengetahuan, kesadaran atau kemauan, dan tindakan untuk nilai-nilai tersebut. Pendidikan karakter dimaksudkan untuk membentuk individu menjadi seorang pribadi bermoral yang dapat menghayati kebebasan dan tanggung jawabnya, dalam relasinya dengan orang lain dan dunianya dalam komunitas pendidikan. Dengan demikian pendidikan karakter senantiasa mengarahkan diri pada pembentukan individu bermoral, cakap mengambil keputusan yang tampil dalam perilaku, sekaligus mampu berperan aktif dalam membangun kehidupan bersama. ${ }^{10}$

\footnotetext{
${ }^{6}$ Doni Koesoema A., Pendidiakn Karakter, Jakarta: Grasindo, 2010, h. 79.

${ }^{7}$ Ahmad Amin, Etika (IImu Akhlaq), Terj. Farid Ma'ruf. Jakarta: Bulan Bintang, Cet. VIII, 1995: 62.

${ }^{8}$ Mike Frye, at all, (Ed.), Character Education: Informational Handbook and Guide for Support and Implementation of the Student Citizent Act of 2001, North Carolina: Public Schools of North Carolina, 2002, h.2.

${ }^{9}$ Ibid., h.3.

${ }^{10}$ Fihris, Pendidikan Karakter di Madrasah Salafiyah, Semarang: PUSLIT IAIN Walisongo, 2010, h.24-28.
} 


\section{Tujuan Pendidikan Karakter}

Manusia secara natural memiliki potensi di dalam dirinya untuk bertumbuh dan berkembang mengatasi keterbatasan manusia dan keterbatasan budayanya. Manusia juga tidak dapat abai terhadap lingkungan sekitarnya. Karena itu, tujuan pendidikan karakter hendaklah diletakkan dalam kerangka gerak dinamis diakletis, berupa tanggapan individu atau impuls natural (fisik dan psikis), sosial, kultural yang melingkupinya, untuk dapat menempa diri menjadi sempurna sehingga potensi-potensi yang ada dalam dirinya berkembang secara penuh dan membuatnya semakin menjadi manusiawi, yang berarti semakin menjadi makhluq yang mampu membuat relasi secara sehat dengan lingkungan di luar dirinya tanpa kehilangan otonomi dan kebebasannya, sehingga ia menjadi manusia yang memiliki sifat tanggungjawab. Pendidikan karakter mengutamakan pertumbuhan moral individu-individu yang ada di dalam lembaga pendidikan. ${ }^{11}$

\section{Dasar Pembentukan Karakter}

Dasar pembentukan karakter itu adalah nilai baik atau buruk. Karakter manusia merupakan hasil tarik-menarik antara nilai baik dalam bentuk energi positif dan nilai buruk dalam bentuk energi negatif. Energi positif itu berupa nilai-nilai etis religius yang bersumber dari keyakinan kepada Tuhan, sedangkan energi negatif itu berupa nilai-nilai yang a-moral yang bersumber dari thaghut atau syaithan. Nilai-nilai etis moral itu berfungsi sebagai sarana pemurni, pensuci dan pembangkit nilai-nilai kemanusiaan yang sejati (hati nurani). Energi positif itu berupa:

a. Kekuatan Spiritual; berupa îmân, islâm, ihsân dan taqwa, yang berfungsi membimbing dan memberikan kekuatan kepada manusia untuk menggapai keagungan dan kemuliaan (ahsanu taqwîm);

b. Kekuatan Potensi Positif; berupa akal yang sehat ('aqlun salim), hati yang sehat (qalbun salîm), hati yang kembali, bersih, suci dari dosa (qalbun munîb) dan jiwa yang tenang (nafsun mutmainnah), yang kesemuanya itu merupakan modal sumber daya manusia yang memiliki kekuatan luar biasa.

c. Sikap dan Perilaku Etis, yang merupakan implementasi dari kekuatan spiritual dan kekuatan kepribadian manusia yang kemudian melahirkan konsep-konsep normatif tentang nilai-nilai budaya etis. Sikap dan perilaku etis itu meliputi: Istiqâmah, ikhlâsh, jihâd dan 'amal shalih.

Energi positif tersebut dalam perspektif individu akan melahirkan orang yang berkarakter, yaitu orang yang bertaqwa, memiliki integritas (nafs al-mutmainnah) dan beramal saleh. Aktualisasi orang yang berkualitas ini dalam hidup dan bekerja akan melahirkan akhlaq budi pekerti yang luhur karena memiliki personality (integritas, komitmen dan dedikasi), capacity (kecakapan) dan competency yang bagus pula (professional).

Kebalikan dari energi positif di atas adalah energi negatif. Energi negatif itu disimbolkan dengan kekuatan materialistik dan nilai-nilai thâghût (nilai-nilai destruktif). Kalau nilai-nilai etis berfungsi sebagai sarana pemurnian, pensucian dan pembangkitan nilai-nilai kemanusiaan yang sejati (hati nurani), nilai-nilai material (thâghût ) justru berfungsi

\footnotetext{
${ }^{11}$ Doni Koesoema A., op.cit., h.134.
} 
sebaliknya yaitu pembusukan, dan penggelapan nilai-nilai kemanusiaan. Hampir sama dengan energi positif, energi negatif terdiri dari:

a. Kekuatan thaghut, berupa kekafiran (kufr), kemunafikan (nifaq), kefasikan (fusuq) dan kemusyrikan (syirk) yang kesemuanya itu merupakan kekuatan yang menjauhkan manusia dari makhluq etis dan kemanusiaannya yang hakiki (ahsani taqwîm) menjadi makhluq yang serba material (asfala sâfilîn);

b. Kekuatan kemanusiaan negatif, yaitu pikiran jahiliyah (pikiran sesat), qalbun marîdl (hati yang sakit, tidak merasa), qalbun mayyit (hati yang mati, tidak punya nurani) dan nafsu 'Ilawwamah (jiwa yang tercela) yang kesemuanya itu akan menjadikan manusia menghamba pada ilah-ilah selain Allah berupa harta, sex dan kekuasaan (thâghût).

c. Sikap dan perilaku tidak etis. Sikap dan perilaku tidak etis ini merupakan implementasi dari kekuatan thâghût dan kekuatan kemanusiaan negatif yang kemudian melahirkan konsepkonsep normatif tentang nilai-nilai budaya tidak etis (budaya busuk). Sikap dan perilaku tidak etis itu meliputi: takabur (congkak), hubb al-dunyâ (materialistik), dlâlim (aniaya) dan amal sayyiât (destruktif).

Energi negatif tersebut dalam perspektif individu akan melahirkan orang yang berkarakter buruk, yaitu orang yang puncak keburukannya meliputi syirk, nafs lawwamah dan 'amal al sayyiât (destruktif). Aktualisasi orang yang bermental thâghût ini dalam hidup dan bekerja akan melahirkan perilaku tercela, yaitu orang yang memiliki personality tidak bagus (hipokrit, penghianat dan pengecut) dan orang yang tidak mampu mendayagunakan kompetensi yang dimiliki. ${ }^{12}$

\section{Pendidikan Karakter dalam Islam}

\section{Melibatkan Banyak Pihak}

Pendidikan karakter merupakan langkah penting dan strategis dalam membangun kembali jati diri individu maupun warga masyarakat, bangsa atau negara. Tapi penting untuk segera dikemukakan bahwa pendidikan karakter harusah melibatkan semua pihak; rumahtangga dan keluarga; sekolah; dan lingkungan sekolah lebih luas (masyarakat). Karena itu, langkah pertama yang harus dilakukan adalah menyambung kembali hubungan dan educational network yang nyaris terputus antara ketiga lingkungan pendidikan ini. Berdasarkan sebuah hadits yang diriwayatkan Anas r.a, keluarga yang baik memiliki empat ciri:

a. Semangat (ghirah) dan kecintaan untuk mempelajari dan menghayati ajaran-ajaran agama dengan sebaik-baiknya untuk kemudian mengamalkan dan mengaktualisasikannya dalam kehidupan.

b. Setiap anggotanya saling menghormati dan menyayangi; saling asah, asih dan asuh.

c. Dalam segi nafkah (konsumsi) tidak berlebih-lebihan; atau tidak serakah dalam usaha mendapatkan nafkah; sederhana atau tidak konsumtif dalam pembelanjaan.

d. Sadar akan kelemahan dan kekurangannya.

Menurut M. Quraish Shihab (1996:321), situasi kemasyarakatan dengan sistem nilai yang dianutnya, mempengaruhi sikap dan cara pandang masyarakat secara keseluruhan. Jika 
sistem nilai dan pandangan mereka terbatas pada "kini dan di sini", maka upaya dan ambisinya terbatas pada kini dan di sini pula. ${ }^{13}$ Dalam konteks tersebut, Al-Qur'an dalam banyak ayatnya menekankan tentang kebersamaan anggota masyarakat menyangkut pengalaman sejarah yang sama, tujuan bersama, gerak langkah yang sama, solidaritas yang sama.

Tujuan pendidikan karakter semestinya diletakkan dalam kerangka gerak dinamis diakletis, berupa tanggapan individu atau impuls natural (fisik dan psikis), sosial, kultural yang melingkupinya, untuk dapat menempa dirinya menjadi sempurna sehingga potensi-potensi yang ada dalam dirinya berkembang secara penuh yang membuatnya semakin menjadi manusiawi dan bertanggung jawab. ${ }^{14}$

\section{Pengembangan Kepribadian Islam}

Dalam pengembangan kepribadian Islam, hal yang paling utama adalah pengembangan hati (qalb). Hati yaitu tempat bermuara segala hal kebaikan ilahiyah karena ruh ada didalamnya. Secara psikologis, hati adalah cerminan baik buruk seseorang. Rasululullah SAW bersabda:

$$
\text { ألا وإن في الجسد مضغة, إذا صلحت صلح الجسد كله, وإذا فسدت فسد الجسد كله, ألا وهي }
$$

\{ketahuilah bahwa dalam jasad terdapat mudghah yang apabila ia baik maka baik pula sluruh tubuh dan apabila ia rusak maka rusaklah seluruh tubuh; ketahuilah, mudghah itu adalah qalb. (HR. Al-Bukhari dari Nu'man bin basyir).

Qalb jika dirawat dan dikembangkan potensinya, cahayanya akan melebihi sinar matahari. la akan menjadi obor sepanjang zaman. Pada pembahasan inilah hakikat pengembangan islam dan mengingat kedudukan hati yng begitu penting, maka unsur pembuka (ladang subur) pembahasannya adalah pendekatan agama.

Pada tahap selanjutnya adalah pengembangan fisik (Jism, jasmani). Fisik yaitu badan dan seluruh anggotanya dapat dilihat dan diraba serta memiliki panca indera sebagai alat pelengkap. Rasul Allah saw bersabda:

$$
\text { المؤمن القوي خير وأحبّ إلى الله من المؤمن الضعيف ... (رواه مسلم) }
$$

\{Seorang mu'min yang kuat lebih baik dan lebih dicintai Allah dibandingkan mu'min yang lemah..." (HR. Muslim).

Untuk mengetahui hal-hal apa yang harus dilakukan selama hidup, maka berikut dikutip dari Al-Qur'an tahap-tahap penciptaan manusia. Allah SWT berfirman:

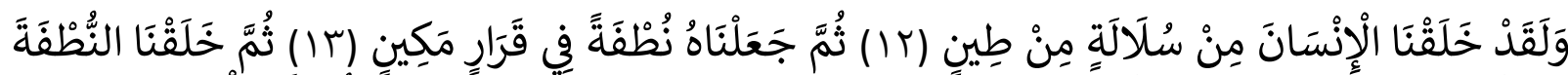

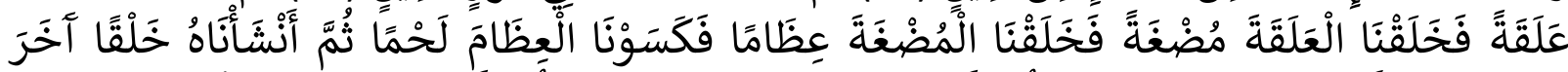

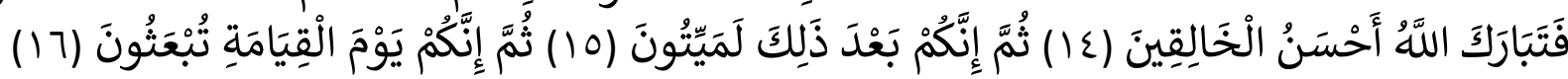
\{dan Sesungguhnya Kami telah menciptakan manusia dari suatu saripati (berasal) dari tanah.(12) kemudian Kami jadikan saripati itu air mani (yang disimpan) dalam tempat yang kokoh (rahim).(13) kemudian air mani itu Kami jadikan segumpal darah, lalu segumpal darah itu Kami jadikan segumpal daging, dan segumpal daging itu Kami jadikan tulang belulang,

\footnotetext{
${ }^{13}$ M. Quraish Shihab, Wawasan Al-Qur'an. Bandung: Mizan, 1996, h. 321.

${ }^{14}$ Fihris, op.cit., h. 55.
} 
lalu tulang belulang itu Kami bungkus dengan daging. kemudian Kami jadikan Dia makhluq yang (berbentuk) lain. Maka Maha sucilah Allah, Pencipta yang paling baik.(14) Kemudian, sesudah itu, Sesungguhnya kamu sekalian benar-benar akan mati.(15) Kemudian, Sesungguhnya kamu sekalian akan dibangkitkan (dari kuburmu) di hari kiamat.(16). (QS. AlMu'minuun/23: 12-16)\}.

Ayat-ayat tersebut menginformasikan asal-usul manusia lengkap dengan batasanbatasan, yaitu dibatasi oleh tanah dari segi fisik dan dibatasi oleh kekuasaan Tuhan dari segi qalb. Manusia yang unggul adalah manusia yang mampu mengembangkan potensi fisik dan psikis. Mencegahnya dari hal-hal yang merusak dan mampu menyembuhkannya jika sudah terlanjur sakit. Dampak dari rusak (sakit)-nya qalb dan jism berdampak pada nafs (psikis). Psikis adalah jiwa, yaitu tempat yang memunculkan gejala yang teraktualisasi dalam bentuk perilaku (amaliah). Jiwa bisa sehat, sakit, atau hanya sekedar terganggu, tergantung dari aspek mana yang paling dominan pengaruhnya. Pepatah arab mengatakan : "tingkah laku lahir itu menunjukkan tungkah laku batin", artinya kondisi nafs dapat dilihat dari bagaimana seseorang berperilaku. Orang yang sedang cemas dan gelisah dapat dilihat dari raut wajahnya yang kusut. Orang yang sedang marah atau malu dapat dilihat dari matanya yang memerah dan sebagainya. Dengan demikian, pengembangan kepribadian merupakan suatu proses yang dinamis. Dalam proses tersebut sifat individu dan sifat lingkungan menentukan tingkah laku apa yang akan menjadi aktual dan terwujud. ${ }^{15}$

\section{Dasar Etika Sosial dalam Islam}

Hubungan manusia dengan Tuhannya adalah hubungan antara makhluq dengan Khaliqnya. Jelas ada subordinasi; makhluq tunduk dan patuh terhadap sang Khaliq. Hubungan antara manusia dengan alam (hewan, tumbuh-tumbuhan, bumi, laut, dan lainnya) adalah hubungan antara penerima amanat sebagai pengelola dengan penerima amanat sebagai yang dikelola: subyek dan obyek. Sedangkan untuk hubungan antar manusia dengan manusia tidak sama dengan kedua bentuk hubungan itu. Untuk itu, Islam mengajarkan konsep-konsep mengenai kedudukan, hak, dan kewajiban serta tanggung jawab manusia. Akibat dari apa yang dilakukan oleh setiap manusia bukan saja mempunyai nilai dan konsekuensi di dunia tapi sekaligus juga di akhirat.

Konsep pertanggung-jawaban di akhirat ini merupakan ciri khas konsep agama. Karena bagaimanapun canggih administrasi, tidak akan pernah terjadi tuntutan tanggung jawab di akhirat. Apapun yang telah di kerjakan, sebagai hal yang baik atau buruk, akan diketahui di akhirat kelak, dan akan dipertanggung jawabkan. Jika hal itu baik, maka pahala yang akan menjadi imbalannya, sedangkan jika hal itu buruk, maka akan ada tuntutan pertanggung jawabannya atas perbuatan buruknya itu. ${ }^{16}$

\section{Dasar-dasar Pendidikan Karakter Perspektif Islam}

Seperti telah dijelaskan sebelum ini bahwa karakter identik dengan akhlaq. Dalam perspektif Islam, karakter atau akhlaq mulia merupakan buah yang dihasilkan dari proses penerapan syari'ah (ibadah dan muamalah) yang dilandasi oleh fondasi 'aqidah yang kokoh. Ibarat bangunan, karakter/akhlaq merupakan kesempurnaan dari bangunan tersebut setelah fondasi dan bangunannya kuat. Jadi, tidak mungkin karakter mulia akan terwujud pada diri

\footnotetext{
${ }^{15}$ Rafy Sapury, Psikologi Islam, Jakarta : PT.Raja grafindo, 2009), h. 114.

${ }^{16}$ A. Qodry Azizy, Pendidikan Agama Untuk Membangun Etika Sosial, Semarang: Aneka Ilmu, 2003, h.93.
} 
seseorang jika ia tidak memiliki 'aqidah dan syari'ah yang benar. Seorang Muslim yang memiliki 'aqidah atau iman yang benar pasti akan terwujud pada sikap dan perilaku sehari-hari yang didasari oleh imannya.

Sebagai contoh, orang yang memiliki iman yang benar kepada Allah ia akan selalu mengikuti seluruh perintah Allah dan menjauhi seluruh larangan-larangan-Nya. Dengan demikian, ia akan selalu berbuat yang baik dan menjauhi hal-hal yang dilarang (buruk). Iman kepada yang lain (malaikat, kitab, dan seterusnya) akan menjadikan sikap dan perilakunya terarah dan terkendali, sehingga akan mewujudkan akhlaq atau karakter mulia. Hal yang sama juga terjadi dalam hal pelaksanaan syari'ah. Semua ketentuan syari'ah Islam bermuara pada terwujudnya akhlaq atau karakter mulia. Seorang yang melaksanakan shalat yang sesuai dengan ketentuan yang berlaku, misalnya, pastilah akan membawanya untuk selalu berbuat yang benar dan terhindar dari perbuatan keji dan munkar. Hal ini dipertegas oleh Allah dalam al-Quran (QS. al-Ankabut/29: 45).

Demikianlah hikmah pelaksanaan syari'ah dalam hal shalat yang juga terjadi pada ketentuan-ketentuan syari'ah lainnya seperti zakat, puasa, haji, dan lainnya. Hal yang sama juga terjadi dalam pelaksanaan muamalah, seperti perkawinan, perekonomian, pemerintahan, dan lain sebagainya. Kepatuhan akan aturan muamalah akan membawa pada sikap dan perilaku seseorang yang mulia dalam segala aspek kehidupannya.

Mengkaji dan mendalami konsep akhlaq bukanlah yang terpenting, tapi merupakan sarana yang dapat mengantarkan seseorang dapat bersikap dan berperilaku mulia seperti yang dipesankan oleh Nabi saw. Dengan pemahaman yang jelas dan benar tentang konsep akhlaq, seseorang akan memiliki pijakan dan pedoman untuk mengarahkannya pada tingkah laku seharihari, sehingga dapat dipahami apakah yang dilakukannya benar atau tidak, termasuk karakter mulia (akhlaq mahmudah) atau karakter tercela (akhlaq madzmumah). Baik dan buruk karakter manusia sangat tergantung pada tata nilai yang dijadikan pijakannya. Abul A'la al-Maududi membagi sistem moralitas menjadi dua:

1. Sistem moral yang berdasar kepada kepercayaan kepada Tuhan dan kehidupan setelah mati.

2. Sistem moral yang tidak mempercayai Tuhan dan timbul dari sumber-sumber sekuler. ${ }^{17}$

Sistem moralitas yang pertama sering juga disebut dengan moral agama, sedang sistem moralitas yang kedua sering disebut moral sekular. Sistem moralitas yang pertama (moral agama) dapat ditemukan pada sistem moralitas Islam (akhlaq Islam). Hal ini karena Islam menghendaki dikembangkannya al-akhlaq al-karimah yang pola perilakunya dilandasi dan untuk mewujudkan nilai Iman, Islam, dan Ihsan. Iman sebagai al-quwwah al-dakhiliah, kekuatan dari dalam yang membimbing orang terus melakukan muraqabah (mendekatkan diri kepada Tuhan) dan muhasabah (melakukan perhitungan) terhadap perbuatan yang akan, sedang, dan sudah dikerjakan. Ubudiyah (pola ibadah) merupakan jalan untuk merealisasikan tujuan akhlaq. Cara pertama untuk merealisasikan akhlaq adalah dengan mengikatkan jiwa manusia dengan ukuranukuran peribadatan kepada Allah.

Karakter tidak akan tampak dalam perilaku tanpa mengikuti aturan-aturan yang ditetapkan oleh Allah SWT ${ }^{18}$ Sedangkan sistem moralitas yang kedua (moral sekular) adalah sistem yang dibuat atau sebagai hasil pemikiran manusia (secular moral philosophies) dengan mendasarkan

\footnotetext{
${ }^{17}$ Abul A'la al-Maududi, Al-Khilafah wa al-Mulk, Terj. Muhammad Al-Baqir. Bandung: Mizan, 1984, h. 9.

${ }^{18}$ Sa'id Hawa, Al-Islam, T.tp.: Maktabah Wahdah, 1977, h. 72.
} 
pada sumber-sumber sekular, baik murni dari hukum yang ada dalam kehidupan, intuisi manusia, pengalaman, maupun karakter manusia. ${ }^{19}$

Sistem moralitas ini merupakan topik pembicaraan para filosof yang sering menjadi masalah penting bagi manusia, sebab sering terjadi perbedaan pendapat mengenai ketetapan baik dan buruknya perilaku, sehingga muncullah berbagai aturan perilaku dengan ketetapan ukuran baik buruk yang berbeda. Sebagai contoh adalah aliran hedonisme yang menekankan pada kebahagiaan, kenikmatan, dan kelezatan hidup duniawi. Terkait dengan paham hedonisme atau utilitarianisme, Ahmad Amin menegaskan:

Di kala memberi hukum kepada sesuatu perbuatan bahwa ia baik atau buruk, wajib kita melihat kelezatan dan kepedihan yang ditimbulkan oleh perbuatan itu, bukan untuk kita sendiri saja, bahkan bagi sesama manusia seluruhnya, segala binatang dan tiap-tiap makhluq yang merasakan kelezatan dan kepedihan dari perbuatannya. Dan hendaklah jangan sampai hanhya melihat kepada kelezatan yang langsung dan dekat, tapi hendaknya meliputi pandangan kita ke arah kelezatan yang tidak langsung dan jauh, lalu menghimpun apa yang ditimbulkan oleh perbuatan itu dari kelezatan dan kepedihan. Apabila kelezatan itu lebih kuat dari kepedihan maka baiklah ia, dan bika kepedihan lebih berat dari kelezatan maka buruklah ia. ${ }^{20}$

Di antara tokoh yang sangat terkenal dalam aliran utilitarianisme adalah Jeremy Bentham dan John Stuart Mill. Aliran yang lain adalah aliran intuisi yang menggunakan kekuatan batiniyah sebagai tolok ukur yang kebenarannya, menurut Islam, bersifat nisbi. Kemudian ada juga aliran adat kebiasan yang memegangi adat kebiasaan yang sudah dipraktikkan oleh kelompok masyarakat sebagai ukurannya tanpa menilai dari sumber nilai universal (al-Quran). Dalam alQuran ditemukan banyak sekali pokok-pokok keutamaan karakter atau akhlaq yang dapat digunakan untuk membedakan perilaku seorang Muslim, seperti perintah berbuat kebaikan (ihsan) dan kebajikan (al-birr), menepati janji (alwafa), sabar, jujur, takut pada Allah SWT, bersedekah di jalan Allah, berbuat adil, dan pemaaf (QS. al-Qashash [28]: 77; QS. al-Baqarah [2]: 177; QS. al-Muminun (23): 1-11; QS. al-Nur [24]: 37; QS. al-Furqan [25]: 35-37; QS. al-Fath [48]: 39; dan QS. Ali 'Imran [3]: 134).

Ayat-ayat tersebut merupakan ketentuan yang mewajibkan pada setiap Muslim melaksanakan nilai karakter mulia dalam berbagai aktivitasnya. Keharusan menjunjung tinggi karakter mulia (akhlaq karimah) lebih dipertegas lagi oleh Nabi saw. dengan pernyataan yang menghubungkan akhlaq dengan kualitas kemauan, bobot amal, dan jaminan masuk surga. Diriwayatkan dari Abdullah Ibn Amr bahwa Nabi SAW bersabda: خيركم خيركم أخلاقا baik kamu adalah yang paling baik akhlaqnya ..." (HR. al-Tirmidzi). Dalam hadis yang lain Nabi SAW bersabda: ..., artinya: "Sesungguhnya orang yang paling cinta kepadaku di antara kamu sekalian dan paling dekat tempat duduknya denganku di hari kiamat adalah yang terbaik akhlaqnya di antara kamu sekalian ..." (HR. al-Tirmidzi). Dijelaskan juga dalam hadis yang lain, ketika Nabi ditanya: "Apa yang terbanyak membawa orang masuk ke dalam surga?" Nabi saw. menjawab: "Taqwa kepada Allah dan berakhlaq baik". (HR. al-Tirmidzi).

Dalil-dalil tersebut menunjukkan bahwa karakter dalam perspektif Islam bukan hanya hasil pemikiran dan tidak berarti lepas dari realitas hidup, melainkan merupakan persoalan yang terkait dengan akal, ruh, hati, jiwa, realitas, dan tujuan yang digariskan oleh akhlaq qur'aniah. ${ }^{21}$ Dengan demikian, karakter mulia merupakan sistem perilaku yang diwajibkan dalam agama

\footnotetext{
${ }^{19}$ Faisal Ismail, Paradigma Kebudayaan Islam. Yogyakarta: Titihan Ilahi Press, 1998, h.181.

${ }^{20}$ Ahmad Amin, op.cit., h. 95-96.

${ }^{21}$ Abu Ainain, Ali Khalil, Falsafah al-Tarbiyah fi al-Quran al-Karim, T.tp.: Dar al-Fikr al-`Arabiy, 1985, h. 186.
} 
Islam melalui nash al-Quran dan hadis. Tapi, kewajiban yang dibebankan kepada manusia bukanlah kewajiban yang tanpa makna dan keluar dari dasar fungsi penciptaan manusia. AlQuran telah menjelaskan masalah kehidupan dengan penjelasan yang realistis, luas, dan juga telah menetapkan pandangan yang luas pada kebaikan manusia dan zatnya. Makna penjelasan itu bertujuan agar manusia terpelihara kemanusiaannya dengan senantiasa dididik akhlaqnya, diperlakukan dengan pembinaan yang baik bagi hidupnya, serta dikembangkan perasaan kemanusiaan dan sumber kehalusan budinya.

Dalam kenyataan hidup memang ditemukan ada orang yang berkarakter mulia dan juga sebaliknya. Ini sesuai dengan fitrah dan hakikat sifat manusia yang bisa baik dan bisa buruk (khairun wa syarrun). Inilah yang ditegaskan Allah dalam firman-Nya, "Maka Allah mengilhamkan kepada jiwa itu (jalan) kefasikan dan ketakwaannya," (QS. al-Syams/91: 8). Manusia telah diberi potensi untuk bertauhid (QS. al-A'raf/7: 172 dan QS. al-Rum/30: 30), maka tabiat asalnya berarti baik, hanya saja manusia dapat jatuh pada keburukan karena memang diberi kebebasan memilih (QS. al-Taubah/9: 7-8 dan QS. al-Kahfi/18: 29).

Dalam surat al-Kahfi Allah SWT menegaskan, "Dan katakanlah: "Kebenaran itu datangnya dari Tuhanmu; maka barangsiapa yang ingin (beriman) hendaklah ia beriman, dan barang siapa yang ingin (kafir) biarlah ia kafir". (QS. al-Kahfi/18: 29). Baik atau buruk bukan sesuatu yang mutlak diciptakan, melainkan manusia dapat memilih beberapa kemungkinan baik atau buruk. Tapi walaupun manusia sudah terjatuh dalam keburukan, ia bisa bangkit pada kebaikan kembali dan bisa bertaubat dengan menghitung apa yang telah dipetik dari perbuatannya. ${ }^{22}$

Kecenderungan manusia pada kebaikan terbukti dalam kesamaan konsep pokok karakter pada setiap peradaban dan zaman. Perbedaan perilaku pada bentuk dan penerapan yang dibenarkan Islam merupkan hal yang ma'ruf. ${ }^{23}$ Tidak ada peradaban yang menganggap baik seperti tindak kebohongan, penindasan, keangkuhan, dan kekerasan. Sebaliknya tidak ada peradaban yang menolak keharusan menghormati kedua orang-tua, keadilan, kejujuran, dan pemaaf sebagai hal yang baik. Tapi, kebaikan yang hakiki tidak dapat diperoleh melalui pencarian manusia dengan akalnya saja. Kebaikan yang hakiki hanyalah diperoleh melalui wahyu dari Allah SWT Karena Allah merupakan Dzat Yang Maha Benar dan pemilik segala kebenaran (QS alBaqarah/2: 147; QS Ali 'Imran/3:60; QS al-Nisa'/4: 170; QS Yunus/10: 94 dan 108; QS. Hud/11: 17; QS al-Kahfi/18: 29; QS. al-Hajj/22: 54; dan QS al-Sajdah/32: 3).

Dengan demikian, karakter telah melekat dalam diri manusia secara fitriah. Dengan kemampuan fitriah ini ternyata manusia mampu membedakan batas kebaikan dan keburukan, dan mampu membedakan mana yang tidak bermanfaat dan mana yang tidak berbahaya. ${ }^{24}$ Harus dipahami bahwa pembawaan fitrah manusia ini tidak serta merta menjadikan karakter manusia bisa terjaga dan berkembang sesuai dengan fitrah tersebut. Fakta membuktikan bahwa pengalaman yang dihadapi masing-masing orang menjadi faktor yang sangat dominan dalam pembentukan dan pengamalan karakternya. Di sinilah pendidikan karakter mempunyai peran yang penting dan strategis bagi manusia dalam rangka melalukan proses internalisasi dan pengamalan nilai-nilai karakter mulia di masyarakat.

Sumber utama penentuan karakter dalam Islam, sebagaimana keseluruhan ajaran Islam lainnya, adalah al-Quran dan Sunnah Nabi Muhammad saw. Ukuran baik dan buruk dalam

\footnotetext{
${ }^{22}$ Ibid., h.104.

${ }^{23}$ M. Quraish Shihab, op.cit., h.255.

${ }^{24}$ Al-Bahi, Sayid Fuad, Asas al-Nafsiyyah li al-Numuwwi min al-Thufulah wa al-Syuyukhah. Kairo: Dar al-Fikr al-'Arabi, 1975 , h.347.
} 
karakter Islam berpedoman pada kedua sumber itu, bukan baik dan buruk menurut ukuran manusia. Sebab jika ukurannya adalah manusia, baik dan buruk akan berbeda-beda. Seseorang mengatakan bahwa sesuatu itu baik, tapi orang lain belum tentu menganggapnya baik. Begitu juga sebaliknya, seseorang menyebut sesuatu itu buruk, padahal yang lain bisa saja menyebutnya baik. Kedua sumber pokok tersebut (al-Quran dan Sunnah) diakui oleh semua umat Islam sebagai dalil naqli yang tidak diragukan otoritasnya. Keduanya hingga sekarang masih terjaga keautentikannya, kecuali Sunnah Nabi yang memang dalam perkembangannya diketahui banyak mengalami problem dalam periwayatannya sehingga ditemukan hadis-hadis yang tidak benar (dla'if/lemah atau maudlu'/palsu). Melalui kedua sumber inilah dapat dipahami dan diyakini bahwa sifat-sifat sabar, qana'ah, tawakkal, syukur, pemaaf, dan pemurah termasuk sifatsifat yang baik dan mulia. Sebaliknya, dapat dipahami pula bahwa sifat-sifat syirik, kufur, nifaq, ujub, takabur, dan hasad merupakan sifat-sifat tercela. Jika kedua sumber itu tidak menegaskan mengenai nilai dari sifat-sifat tersebut, akal manusia mungkin akan memberikan penilaian yang berbeda-beda.

Islam tidak mengabaikan adanya standar lain selain al-Quran dan sunnah/hadis untuk menentukan baik dan buruk dalam hal karakter manusia. Standar lain dimaksud adalah akal dan nurani manusia serta pandangan umum (tradisi) masyarakat. Manusia dengan hati nuraninya dapat juga menentukan ukuran baik dan buruk, sebab Allah memberikan potensi dasar (fitrah) kepada manusia berupa tauhid dan kecerdasan (QS al-A'raf/7:172; QS al-Rum/30:30; QS alBaqarah/2:31; dan QS al-Sajdah/32:9).

Dengan fitrah itulah manusia akan mencintai kesucian dan cenderung kepada kebenaran. Hati nuraninya selalu mendambakan dan merindukan kebenaran, ingin mengikuti ajaran-ajaran Allah dan Rasul-Nya, karena kebenaran itu tidak akan dicapai kecuali dengan Allah sebagai sumber kebenaran mutlak. Tapi, harus diakui bahwa fitrah manusia tidak selalu dapat berfungsi dengan baik. Pendidikan dan pengalaman manusia dapat memengaruhi eksistensi fitrah manusia itu. Dengan pengaruh tersebut tidak sedikit fitrah manusia menjadi kotor dan tertutup sehingga tidak lagi dapat menentukan baik dan buruk dengan benar. Karena itulah ukuran baik dan buruk tidak dapat diserahkan kepada hati nurani belaka, tapi harus dikembalikan kepada wahyu yang terjamin kebenarannya. ${ }^{25}$

Akal pikiran manusia sama kedudukannya seperti hati nurani. Kebaikan atau keburukan yang diperoleh akal bersifat subjektif dan relatif. Karena itu, akal manusia tidak dapat menjamin ukuran baik dan buruknya karakter manusia. Hal yang sama juga terjadi pada pandangan umum (tradisi) masyarakat. Yang terakhir ini juga bersifat relatif, bahkan nilainya paling rendah dibandingkan kedua standar sebelumnya. Hanya masyarakat yang memiliki kebiasaan (tradisi) yang baik yang dapat memberikan ukuran yang lebih terjamin.

\section{E. Ruang Lingkup Pendidikan Karakter Perspektif Islam}

Secara umum karakter dalam perspektif Islam dibagi menjadi dua, yaitu karakter mulia (alakhlaq al-mahmudah) dan karakter tercela (al-akhlaq almadzmumah). Karakter mulia harus diterapkan dalam kehidupan setiap Muslim sehari-hari, sedang karakter tercela harus dijauhkan dari kehidupan setiap Muslim. Jika dilihat dari ruang lingkupnya, karakter Islam dibagi menjadi dua bagian, yaitu karakter terhadap Khaliq (Allah SWT) dan karakter terhadap makhluq (makhluq/selain Allah SWT). Karakter terhadap makhluq bisa dirinci lagi menjadi beberapa macam, seperti karakter terhadap sesama manusia, karakter terhadap makhluq hidup selain

\footnotetext{
${ }^{25}$ Yunahar llyas, Kuliah Akhlaq, Yogyakarta: LPPI UMY, 2004, h.4.
} 
manusia (seperti tumbuhan dan binatang), serta karakter terhadap benda mati (lingkungan alam). Berikut ini perinciannya.

\section{Karakter Terhadap Khaliq (Allah)}

Islam menjadikan 'aqidah sebagai fondasi syari'ah dan akhlaq. Karena itu, karakter yang mula-mula dibangun setiap Muslim adalah karakter terhadap Allah SWT Ini bisa dilakykan misalnya dengan cara menjaga kemauan dengan meluruskan ubudiyah dengan dasar tauhid (QS al-Ikhlash/112:1-4; QS al-Dzariyat/51:56), menaati perintah Allah atau bertakwa (QS Ali 'Imran/3: 132), ikhlas dalam semua amal (QS al-Bayyinah/98:5), cinta kepada Allah (QS alBaqarah/2:165), takut kepada Allah (QS. Fathir/35: 28), berdoa dan penuh harapan (raja') kepada Allah SWT (QS al-Zumar/39:53), berdzikir (QS al-Ra'd/13:28), bertawakal setelah memiliki kemauan dan ketetapan hati (QS Ali 'Imran/3: 159; QS Hud/11: 123), bersyukur (QS al-Baqarah/2: 152 dan QS Ibrahim/14: 7), bertaubat serta istighfar bila berbuat kesalahan (QS al-Nur/24]: 31 dan QS al-Tahrim/66: 8), rido atas semua ketetapan Allah (QS al-Bayyinah/98: 8), dan berbaik sangka pada setiap ketentuan Allah (QS Ali 'Imran/3: 154). Selanjutnya setiap Muslim juga dituntut untuk menjauhkan diri dari karakter tercela terhadap Allas SWT, misalnya: syirik (QS al-Maidah/5:72,73; QS al-Bayyinah/98: 6); kufur (QS al-Nisa'/4:136); dan melakukan hal-hal yang bertentangan dengan karakter-karakter mulia terhadap Allah.

\section{Karakter Terhadap Rasul Allah}

Sebelum seorang Muslim mencintai sesamanya, bahkan terhadap dirinya, ia harus terlebih dahulu mencintai Allah dan Rasul Allah. Kualitas cinta kepada sesama tidak boleh melebihi kualitas cinta kepada Allah dan Rasul Allah (QS al-Taubah/9: 24). Karakter yang lain terhadap Rasul Allah adalah taat kepadanya dan mengikuti sunnahnya (QS al-Nisa'/4: 59) serta mengucapkan shalawat dan salam kepadanya (QS al-Ahzab/33:56). Islam melarang mendustakan Rasul Allah dan mengabaikan sunnah-sunnahnya.

\section{Karakter dalam Diri Sendiri}

Islam juga mengajarkan kepada setiap Muslim untuk berkarakter mulia terhadap dirinya sendiri. Manusia yang telah diciptakan dalam sibghah Allah SWT dan dalam potensi fitriahnya berkewajiban menjaganya dengan cara memelihara kesucian lahir dan batin (QS. al-Taubah [9]: 108), memelihara kerapihan (QS al-A'raf/7: 31), menambah pengetahuan sebagai modal amal (QS al-Zumar/39: 9), membina disiplin diri (QS al-Takatsur/102: 1-3), dan lain-lainnya. Sebaliknya Islam melarang seseorang berbuat aniaya terhadap dirinya (QS al-Baqarah/2:195); melakukan bunuh diri (QS al-Nisa'/4: 29-30); minum minuman keras atau yang sejenisnya dan suka berjudi (QS al-Maidah/5: 90-91); dan yang lainnya.

\section{Karakter dalam Keluarga}

Selanjutnya setiap Muslim harus membangun karakter dalam lingkungan keluarganya. Karakter mulia terhadap keluarga dapat dilakukan misalnya dengan berbakti kepada kedua orang tua (QS al-Isra'/17: 23), bergaul dengan ma'ruf (QS al-Nisa'/4: 19), memberi nafkah dengan sebaik mungkin (QS al-Thalaq/65: 7), saling mendoakan (QS al-Baqarah/2: 187), bertutur kata lemah lembut (QS al-Isra'/17: 23), dan lain sebagainya. Setiap Muslim jangan sekali-kali melakukan yang sebaliknya, misalnya berani kepada kedua orang tua, suka bermusuhan, dan lain sebagainya.

\section{Karakter Terhadap Tetangga}


Terhadap tetangga, seorang Muslim harus membina hubungan baik tanpa harus memperhatikan perbedaan agama, etnis, bahasa, dan yang semisalnya. Tetangga adalah sahabat yang paling dekat. Begitulah Nabi menegaskan dalam sabdanya, "Tidak hentihentinya Jibril menyuruhku untuk berbuat baik pada tetangga, hingga aku merasa tetangga sudah seperti ahli waris" (HR. al-Bukhari). Bertolak dari hal ini Nabi saw. memerinci hak tetangga sebagai berikut:

a. Mendapat pinjaman secukupnya,

b. Mendapat pertolongan secukupnya,

c. Mendapat ucapan selamat jika mendapat kemenangan/kesenangan,

d. Dikunjungi bila sakit,

e. Dibantu keperluannya/dari kemiskinannya,

f. Dihibur jika susah,

g. Diantar jenazahnya jika meninggal,

h. Tidak dibenarkan membangun rumah lebih tinggi tanpa seizinnya,

i. Tidak boleh disusahkan dengan bau masakan,

j. Mendapat bagian dari apa yang kamu beli, atau. jangan diperlihatkan jika tidak diberi" (HR. Abu Syaikh).

Inilah karakter yang harus diamalkan setiap Muslim terhadap tetangga, jangan sampai ia melakukan hal yang sebaliknya.

\section{Karakter Terhadap Masyarakat}

Setiap Muslim juga harus membina hubungan baik di masyarakat. Dalam pergaulan di masyarakat setiap Muslim harus dapat berkarakter sesuai dengan status dan posisinya masing-masing. Jika sebagai pemimpin, seorang Muslim hendaknya memiliki karakter mulia seperti beriman dan bertakwa, berilmu pengetahuan cukup agar semua urusan dapat ditangani secara profesional dan tidak salah urus, memiliki keberanian dan kejujuran, lapang dada, dan penyantun (QS Ali 'Imran/3:159), serta didukung dengan ketekunan, kesabaran, dan melindungi rakyat yang dipimpinnya. Dari bekal sikap inilah pemimpin akan dapat melaksanakan tugasnya dengan penuh tanggung jawab, memelihara amanah, adil (QS alNisa'/4: 58), melayani dan melindungi rakyat (sabda Nabi riwayat Muslim), dan membelajarkan rakyat. Ketika menjadi rakyat, seorang Muslim harus patuh kepada pemimpinnya (QS al-Nisa'/4: 59), memberi saran dan nashihat jika ada tanda-tanda penyimpangan (sabda Nabi riwayat Abu Daud).

\section{Karakter Terhadap Lingkungan}

Lingkungan yang dimaksud adalah segala sesuatu yang berada di sekitar manusia, yakni binatang, tumbuhan, dan alam sekitar (benda mati). Karakter yang dikembangkan adalah cerminan dari tugas kekhalifahan manusia di bumi, yakni untuk menjaga agar setiap proses pertumbuhan alam terus berjalan sesuai dengan fungsi ciptaan-Nya. Dalam al-Quran Surat alAn'am/6:38 dijelaskan bahwa binatang melata dan burung-burung adalah seperti manusia, yang menurut al-Qurtubi, sebagaimana dikuti Quraish Shihab, tidak boleh dianiaya, ${ }^{26}$ baik di medan perang ataupun ketika damai. Islam menganjurkan agar tidak ada pengrusakan binatang dan tumbuhan kecuali terpaksa, tapi sesuai dengan sunnatullah dari tujuan dan fungsi penciptaan (QS al-Hasyr/59: 5).

\footnotetext{
${ }^{26}$ M. Quraish Shihab, op.cit., h. 270.
} 


\section{F. Pola Pengembangan Karakter Perspektif Islam}

Pengalaman Nabi Muhammad membangun masyarakat Arab hingga menjadi manusia yang berkarakter mulia (masyarakat madani) memakan waktu yang cukup panjang. Pembinaan ini dimulai dari membangun 'aqidah mereka selama kurang lebih tiga belas tahun, yakni ketika Nabi masih berdomisili di Makkah. Selanjutnya selama kurang lebih sepuluh tahun Nabi melanjutkan pembentukan karakter mereka dengan mengajarkan syari'ah (hukum Islam) untuk membekali ibadah dan muamalah mereka sehari-hari. Dengan modal 'aqidah dan syari'ah serta didukung dengan keteladanan sikap dan perilakunya, Nabi berhasil membangun masyarakat madani (yang berkarakter mulia). Masyarakat berkarakter ini terus berlanjut pada masa-masa selanjutnya sepeninggal Nabi hingga berakhirnya masa al-khulafa' al-rasyidun (para khalifah yang bijak).

Para ahli akhlaq (etika) Islam memberikan wacana yang bervariasi dalam rangka pencapaian manusia paripurna (insan kamil) yang dipengaruhi oleh landasan teologis yang bervariasi pula. Majid Fakhry mengupas secara detail pemikiran para ahli etika Islam dengan mendasarkan pada karya-karya mereka yang monumental. Mereka adalah Hasan al-Bashri, Ibnu Abi al-Dunya, Abu al-Hasan al-Mawardi, Ali Ibn Ahmad Ibn Hazm, al-Raghib al-Asfahani, Fahkhr al-Din al-Razi, dan al-Ghazali. Dari karya-karya merekalah, Majid Fakhry mencoba menemukan ide-ide tentang pengembangan etika religius (Islam) secara bervariasi, terutama dalam rangka pencapaian menjadi manusia suci atau dalam kajian ini disebut manusia berkarakter (mulia).

Di antara tokoh-tokoh etika tersebut yang idenya relevan dalam tulisan adalah al-Raghib al-Asfahani dan al-Ghazali. Al-Asfahani menuangkan ide-ide penyucian jiwa (berkarakter mulia) bagi manusia dalam kitabnya yang diberi judul al-Dzari'ah ila Makarim al-Syari'ah. Menurut alAsfahani, landasan kemuliaan agama adalah kesucian jiwa yang dicapai melalui pendidikan dan melakukan kesederhanaan, kesabaran, dan keadilan. Kesempurnaannya diperoleh dari kebijaksanaan yang ditempuh melalui pelaksanaan perintah-perintah agama, kedermawanan dicapai melalui kesederhanaan, keberanian dicapai melalui kesabaran, dan kebenaran berbuat diperoleh melalui keadilan (Majid Fakhry, 1996: 102). Itulah keterkaitan yang sangat erat antara agama dengan karakter seseorang. Ditambahkan, bahwa siapa saja yang memenuhi persyaratan tersebut ia akan memperoleh tingkat kemuliaan tertinggi yang oleh al-Quran (QS. al-Hujurat/49: 13) adalah ketakwaan. Di samping itu, ia akan menjadi khalifat yang mulia di muka bumi dan memasuki tingkatan ketuhanan, syahid, dan orang suci. ${ }^{27}$

Al-Asfahani membedakan kemuliaan agama dengan ketaatan beragama. Dalam pandangannya, ketaatan beragama terbatas pada ritus-ritus (peribadatan), sedang kemuliaan agama sama sekali tidak terbatas. Aturan-aturan yang berlaku bagi ketaatan beragama adalah kewajiban (fardlu) untuk memilih (nafal) atau keadilan ('adl) untuk mencapai keutamaan (fadll). Dengan melaksanakan keadilan manusia diperbolehkan melakukan kewajiban yang menjadi prasyarat utama. $^{28}$

Al-Asfahani juga menjelaskan hubungan yang erat antara aktivitas agama dengan karakter (akhlaq). Hubungan keduanya, menurutnya, sangat organis. Menurutnya, ibadah merupakan prasarat bagi terwujudnya karakter mulia. la menegaskan, Tuhan tidak memerintahkan kewajiban beribadah kepada manusia demi keuntungan-Nya, karena Tuhan Maha Kaya, tapi Tuhan memerintahkan kewajiban itu kepada manusia dengan tujuan membersihkan ketidaksucian dan penyakitpenyakit jiwa manusia, yang dengannya manusia akan mampu

\footnotetext{
${ }^{27}$ Majid Fakhry, Etika dalam Islam. Terj. oleh Zakiyuddin Baidhawi. Yogyakarta: Pustaka Pelajar, 1996, h. 103.

${ }^{28}$ Ibid.
} 
mencapai kehidupan abadi dan sejahtera di kemudian hari. Menurut al-Asfahani penyucian diri hanya mungkin dilakukan melalui perbuatan yang selaras dengan hukum agama di satu sisi dan melalui penanaman perilaku moral dan kedewasaan intelektual yang secara filosofis ditekankan oleh para ahli moral sebagai prasarat bagi kewajiban moral. ${ }^{29}$

Selanjutnya, al-Asfahani membagi kekuatan jiwa menjadi tiga macam, yaitu kekuatan kekuatan rasional, kekuatan seksual, dan kekuatan amarah. Kesucian jiwa seseorang bisa dicapai dengan mensucikn tiga kekuatan tersebut. Menurutnya, kekuatan rasional bisa diperbaiki melalui pendidikan, sehingga memungkinkan untuk membedakan antara kebenaran dan kepalsuan baik dalam dimensi teoritis maupun praktis. Kekuatan seksual diperbaiki melalui kedermawanan dan kesabaran. Sedang kekuatan amarah (hamiyah) diperbaiki melalui penjinakan secara bertahap, sehingga jiwa benar-benar dapat dikendalikan dan keberanian dapat diperoleh. Ketika semua kekuatan ini menjadi baik, maka keadilan dan kebaikan akan diperoleh. ${ }^{30}$

Dengan proses inilah seseorang akan benar-benar mencapai karakter mulia (al-akhlaq alkarimah). Sementara itu, al-Ghazali menuangkan ide-ide perbaikan moral manusia melalui dua bukunya yang sangat terkenal, yaitu Mizan al-'Amal (Kriteria Perbuatan) dan Ihya' 'Ulum al-Din (Menghidupkan Ilmu-ilmu Agama). Al-Ghazali mendasari ide-ide akhlaqnya dengan menegaskan bahwa akhlaq atau karakter yang baik adalah sifat-sifat yang dimiliki oleh Rasul Allah, sehingga ayat-ayat al-Quran yang berkaitan dengan akhlaq banyak ditujukan kepada Rasul Allah (Muhammad saw.), misalnya dalam ayat: وَأَنَّكَ لَعَلَى خُحُقِ عَظِيمٍ (Sesungguhnya engkau (Muhammad) adalah manusia yang berkarakter agung. (QS al-Qalam/68:4)\}. ${ }^{31}$

Al-Ghazali menawarkan beberapa formula untuk bisa mencapai karakter mulia. Al-Ghazali membagi jiwa menjadi dua bagian, yaitu jiwa binatang dan jiwa manusia. Jiwa binatang memiliki kekuatan gerak, nafsu, dan persepsi; sedang jiwa manusia memiliki kekuatan untuk mengetahui dan berbuat atau kekuatan teoritis dan praktis. Kekuatan praktislah yang menggerakkan tubuh manusia untuk melakukan perbuatan tertentu yang melibatkan refleksi dan kesengajaan yang diarahkan oleh kekuatan teoritis atau pengetahuan. Ketika kekuatan-kekuatan untuk memenuhi kebutuhan jasmaniah dapat ditaklukkan oleh kekuatan praktis, maka sifat-sifat yang baik akan muncul dalam jiwa; sebaliknya jika kekuatan praktis ditaklukkan oleh kekuatankekuatan untuk memenuhi kebutuhan jasmaniah, maka sifat-sifat kejilah yang akan tampak. ${ }^{32}$

Al-Ghazali menetapkan tiga tahapan dalam rangka pengendalian nafsu:

1. Manusia ditundukkan oleh kekuatan hawa nafsu, sehingga hawa nafsu sangat ditaati, bahkan manusia mengabdi kepadanya, seperti disebutkan dalam al-Quran:

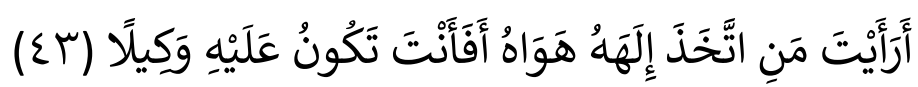

\{Terangkanlah kepadaku tentang orang yang menjadikan hawa nafsunya sebagai Tuhannya. Maka Apakah kamu dapat menjadi pemelihara atasnya? (QS al-Furqan/25: 43)\}. Di tataran inilah kebanyak orang berada.

2. Manusia tetap berperang melawan hawa nafsu yang memungkinkan untuk kalah atau menang. Kondisi ini merupakan tingkat tertinggi kemanusiaan selain yang dimiliki oleh para nabi dan orang suci.

\footnotetext{
${ }^{29}$ Ibid, h.104.

${ }^{30} \mathrm{lbid}$.

${ }^{31}$ lbid, h. 126.

${ }^{32}$ Ibid., h. 129.
} 
3. Manusia mampu mengatasi hawa nafsunya dan sekaligus menundukkannya. Ini adalah keberhasilan besar dan dengannya manusia akan merasakan kenikmatan yang ada (al-na'im alhadlir), kebebasan, dan terlepas dari hawa nafsu. ${ }^{33}$

Orientasi pencapaian karakter mulia dalam pandangan al-Ghazali banyak didasarkan pada proses pengendalian hawa nafsu. Fondasi etika yang juga sangat ditekankan oleh al-Ghazali adalah tuntutan mistik bagi jiwa untuk selalu berusaha mencari Tuhan. Al-Ghazali sangat mencela:

1. Ketololan manusia pada saat kehilangan atau tidak mendapatkan kepemilikan duniawi,

2. Prasaan duka cita yang disebabkan oleh penderitaan duniawi, dan kesombongan karena merasa kebal terhadap ketentuan Tuhan.

3. Perasaan takut akan kematian. Menurutnya, manusia yang benar-benar berakal adalah justeru akan memikirkan kematian, mempersiapkan diri tawakkal.

4. Berbuat zhalim, meninggalkan kecemburuan dan kekhawatiran terhadap kepemilikan duniawi,

Seharusnya manusia menanamkan kebiasaan merasa puas ( $\left.q a n a^{\prime} a h\right)$ terhadap apa yang diperolehnya, selalu menyesali diri atas dosa yang diperbuatnya, serta mempersiapkan diri untuk bertemu dengan Tuhan dengan kebahagiaan yang tak terhingga. ${ }^{34}$ Demikianlah proses pencapaian tingkatan mencari Tuhan (ma'rifatullah) dalam pandangan al-Ghazali yang merupakan salah satu kriteria manusia paripurna (insan kamil).

Michele Borba menggunakan istilah "membangun kecerdasan moral" untuk pendidikan karakter. Dia menulis sebuah buku dengan judul Building Moral Intelligence: The Seven Essential Vitues That Kids to Do The Right Thing, 2001 (Membangun Kecerdasan Moral: Tujuh Kebajikan Utama Agar Anak Bermoral Tinggi, 2008). Kecerdasan moral, menurut Michele Borba (2008: 4), adalah kemampuan seseorang untuk memahami hal yang benar dan yang salah, yakni memiliki keyakinan etika yang kuat dan bertindak berdasarkan keyakinan tersebut, sehingga ia bersikap benar dan terhormat. adalah sifat-sifat utama yang dapat mengantarkan seseorang menjadi baik hati, berkarakter kuat, dan menjadi warga negara yang baik.

Bagaimana cara menumbuhkan karakter yang baik dalam diri anak-anak disimpulkannya menjadi tujuh cara yang harus dilakukan anak untuk menumbuknan kebajikan utama (karakter yang baik), yaitu empati, hati nurani, kontrol diri, rasa hormat, kebaikan hati, toleransi, dan keadilan. Ketujuh macam kebajikan inilah yang dapat membentuk manusia berkualitas di mana pun dan kapan pun. Meskipun sasaran buku ini adalah anak-anak, tapi bukan berarti tidak berlaku untuk orang dewasa. Dengan kata lain tujuh kebajikan yang ditawarkan oleh Michele Borba ini berlaku untuk siapa pun dalam rangka membangun kecerdasan moralnya.

1. Empati merupakan inti emosi moral yang membantu anak memahami perasaan orang lain. Kebajikan ini membuatnya menjadi peka terhadap kebutuhan dan perasaan orang lain, mendorongnya menolong orang yang kesusahan atau kesakitan, serta menuntutnya memperlakukan orang dengan kasih sayang.

2. Hati nurani adalah suara hati yang membantu anak memilih jalan yang benar daripada jalan yang salah serta tetap berada di jalur yang bermoral; membuat dirinya merasa bersalah ketika menyimpang dari jalur yang semestinya.

\footnotetext{
33 Ibid., h.131.

34 Ibid., h.139.
} 
3. Kontrol diri dapat membantu anak menahan dorongan dari dalam dirinya dan berpikir sebelum bertindak, sehingga ia melakukan hal yang benar, dan kecil kemungkinan mengambil tindakan yang berakibat buruk. Kebajikan ini membantu anak menjadi mandiri karena ia tahu bahwa dirinya bisa mengendalikan tindakannya sendiri. Sifat ini membangkitkan sikap moral dan baik hati karena ia mampu menyingkirkan keinginan memuaskan diri serta merangsang kesadaran mementingkan keperluan orang lain.

4. Rasa hormat mendorong anak bersikap baik dan menghormati orang lain. Kebajikan ini mengarahkannya memperlakukan orang lain sebagaimana ia ingin orang lain memperlakukan dirinya, sehingga mencegahnya bertindak kasar, tidak adil, dan bersikap memusuhi. Dengan ini ia akan memerhatikan hak-hak serta perasaan orang lain.

5. Kebaikan hati membantu anak menunjukkan kepeduliannya terhadap kesejahteraan dan perasaan orang lain. Dengan mengembangkan kebajikan ini, ia lebih berbelas kasih terhadap orang lain dan tidak memikirkan diri sendiri, serta menyadari perbuatan baik sebagai tindakan yang benar.

6. Toleransi membuat anak mampu menghargai perbedaan kualitas dalam diri orang lain, membuka diri terhadap pandangan dan keyakinan baru, dan menghargai orang lain tanpa membedakan suku, gender, penampilan, budaya, agama, kepercayaan, kemapuan, atau orientasi seksual. Dengan toleransi ia akan memperlakukan orang lain dengan baik dan penuh pengertian, menentang permusuhan, kekejaman, kefanatikan, serta menghargai orang-orang berdasarkan karakter merea.

7. Keadilan menuntun anak agar memperlakukan orang lain dengan baik, tidak memihak, dan adil, sehingga ia mematuhi aturan, mau bergiliran dan berbagi, serta mendengar semua pihak secara terbuka sebelum memberi penilaian apa pun. la juga terdorong untuk membela orang lain yang diperlakukan tidak adil dan menuntut agar setiap orang diperlakukan setara. ${ }^{35}$

Tujuh kebajikan itu menjadi pola dasar dalam membentuk karakter (akhlaq) mulia dari sisi kemanusiaannya hingga sepanjang hidup ia akan menggunakannya. Untuk mendasari itu semua perlu terlebih dahulu diajarkan berbagai nilai kebajikan yang harus direalisasikan dalam perilaku nyata oleh setiap manusia dalam kehidupannya sehari-hari. Dengan cara demikian seseorang akan mendapatkan kualitas sebagai insan kamil, insan yang berakhlaq mulia, atau dengan istilah Michele Borba disebut manusia yang memiliki kecerdasan moral.

Howard Kirschenbaum, dalam salah satu bukunya, 100 Ways to Enhance Values and Morality in Schools and Youth Settings (1995), menguraikan 100 cara untuk bisa meningkatkan nilai dan moralitas (karakter/akhlaq mulia) di sekolah yang bisa dikelompokkan ke dalam lima metode, yaitu:

1. Penanaman nilai-nilai dan moralitas (Inculcating values and morality);

2. Pemodelan nilai-nilai dan moralitas (Modeling values and morality);

3. Memfasilitasi nilai-nilai dan moralitas (Facilitating values and morality);

4. Ketrampilan untuk pengembangan nilai dan literasi moral (Skills for value development and moral literacy);

5. Pengembangan program pendidikan nilai (Developing a values education program).

Dari pendapat Kirschenbaum ini maka seorang pendidik harus merancang roses pendidikan yang berpedoman pada lima program tersebut. Pendidikan Islam jika dirancang dengan model Kirschenbaum tersebut, tentu akan semakin cepat membuahkan hasilnya.

${ }^{35}$ Michele Borba, Membangun Kecerdasan Moral: Tujuh Kebajikan Utama Agar Anak Bermoral Tinggi, Terj. Lina Jusuf. Jakarta: PT. Gramedia Pustaka Utama, 2008, h. 7-8. 
Dua pola pengembangan karakter yang ditawarkan oleh para tokoh etika Islam dan para tokoh sekular, terlihat jelas perbedaannya. Para tokoh etika Islam mendasari pengembangan karakter manusia dengan fondasi teologis ('aqidah) yang benar, meskipun pemahaman teologi mereka berbeda-beda. Dengan fondasi teologis itulah mereka membangun ide bagaimana seharusnya manusia dapat mencapai kesempurnaan agamanya sehingga menjadi orang yang benar-benar berkarakter mulia. Sedang para tokoh sekuler lebih menekankan para proses apa yang harus ditempuh oleh seseorang dalam rangka mencapai tujuan itu. Proses ini sama sekali mengabaikan landasan teologi ('aqidah).

Proses inilah yang sekarang banyak dikembangkan di lembaga-lembaga pendidikan baik formal, nonformal, maupun informal, karena hasilnya lebih mudah dan cepat terlihat. Tapi, harus diakui ketiadaan fondasi teologis ('aqidah) tidak bisa menjamin untuk terwujudnya karakter mulia dalam diri seseorang yang sebenarnya, terutama dalam perspektif Islam. Karakter, dalam pandangan tokoh etika sekular, hanya terfokus pada hubungan manusia dengan sesamanya atau dengan alam sekitarnya, sementara dalam pandangan tokoh etika Islam karakter harus dimulai dengan membangun hubungan yang baik dengan Allah dan Rasul Allah, lalu berlanjut pada hubungan dengan sesamanya dan dengan lingkungannya.

\section{G. Penutup}

Jika umat Islam Indonesia sebagai mayoritas penduduk negeri ini memiliki karakter mulia, maka Indonesia telah berhasil membangun karakter bangsanya. Tapi jika umat Islam Indonesia hanya bangga dalam hal kuantitas, tanpa memperhatikan kualitas (terutama karakter), maka Indonesia gagal membangun bangsanya. Artinya, jika umat Islam benar-benar memahami ajaran agama Islam dengan baik, lalu mengamalkannya dalam kehidupan sehari-hari, pastilah terwujud tatanan kehidupan di tengah-tengah masyarakat yang berkarakter.

Tapi kenyataan membuktikan bahwa Indonesia banyak bermasalah dalam hal karakter. Hal ini berarti bangsa Indonesia yang mayoritasnya umat Islam belum mengamalkan ajaran agamanya dengan baik. Ide-ide dua tokoh etika Islam (al-Asfahani dan al-Ghazali) seperti yang telah diuraikan, bisalah dijadikan sandaran dalam meyakini kesimpulan tersebut. Dapatlah ajaran agama Allah yang haqq (Islam) dijadikan sebagai landasan utama dalam membangun karakter manusia, termasuk bangsa Indonesia ini. Dengan ajaran Islam karakter manusia seutuhnya (berakhlaq mulia) bisa terbangun.

$$
\Phi \phi \Phi
$$

\section{K. Daftar Pustaka}

Ali Khalil, Abu Ainain, Falsafah al-Tarbiyah fi al-Quran al-Karim, T.tp.: Dar al-Fikr al-'Arabiy, 1985.

Al-Bahi, Sayid Fuad, Asas al-Nafsiyyah li al-Numuwwi min al-Thufulah wa al-Syuyukhah, Kairo: Dar al-Fikr al-'Arabiy, 1975.

Al-Maududi, Abul A’la, Al-Khilafah wa al-Mulk, Terj. Muhammad Al-Baqir, Bandung: Mizan, 1984.

Amin, Ahmad, Etika (IImu Akhlaq). Terj. oleh Farid Ma'ruf, Jakarta: Bulan Bintang, Cet. VIII, 1995. 
Borba, Michele, Membangun Kecerdasan Moral: Tujuh Kebajikan Utama Agar Anak Bermoral Tinggi, Terj. Lina Jusuf. Jakarta: PT. Gramedia Pustaka Utama, 2008.

Departemen Agama RI, Al-Qur'an dan Terjemahnya, Jakarta: epartemen Agama RI, 1984.

Echols, M. John dan Shadily, Hassan, Kamus Inggris Indonesia: An English-Indonesian Dictionary, Jakarta: PT Gramedia. Cet. XXI, 1995.

Frye, Mike, at all. (Ed.), Character Education: Informational Handbook and Guide for Support and Implementation of the Student Citizent Act of 2001, North Carolina: Public Schools of North Carolina,2002.

Hawa, Sa'id, Al-Islam, T.tp.: Maktabah Wahdah, 1977.

Ilyas, Yunahar, Kuliah Akhlaq, Yogyakarta: LPPI UMY, 2004.

Ismail, Faisal, Paradigma Kebudayaan Islam, Yogyakarta: Titihan Ilahi Press, 1998.

Kirschenbaum, Howard, 100 Ways to Enhance Values and Morality in Schools and Youth Settings, Massachusetts: Allyn \& Bacon, 1995.

Lickona, Thomas, Educating for Character: How Our School Can Teach Respect and Responsibility, New York, Toronto, London, Sydney, Aucland: Bantam books, 1991.

Majid Fakhry, Etika dalam Islam, Terj. oleh Zakiyuddin Baidhawi, Yogyakarta: Pustaka Pelajar, 1996.

Marzuki, Prinsip Dasar Akhlaq Mulia: Pengantar Studi Konsep-Konsep Dasar Etika dalam Islam, Yogyakarta: Debut Wahana Press-FISE UNY, 2009.

Pusat Bahasa Departemen Pendidikan Nasional, Kamus Bahasa Indonesia, Jakarta: Pusat Bahasa. Cet. I, 2008.

Ryan, Kevin \& Bohlin, Karen E., Building Character in Schools: Practical Ways to Bring Moral Instruction to Life, San Francisco: Jossey Bass, 1999.

Shihab, M. Quraish, Wawasan Al-Qur'an, Bandung: Mizan, 1996.

$\Phi \Phi \Phi$ 